\title{
Quality Index Method developed for Frigate tuna (Auxis thazard)
}

\author{
K.W.S. ARIYAWANSA**1, D.N. WIJENDRA ${ }^{2}$ AND S.P.S.D. \\ SENADHEERA ${ }^{1}$ \\ ${ }^{1}$ Post Harvest Technology Division \\ National Aquatic Resources Research and Development Agency \\ Crow Island, Colombo 15, Sri Lanka \\ 2 Department of Chemistry, University of Sri Jayawardenapura \\ Sri Lanka
}

*Corresponding author: sujeewa@nara.ac.lk

\section{Abstract}

An investigation was carried out to develop and evaluate a Quality Index Method (QIM) scheme for Frigate tuna (Auxis thazard) for the prediction of past and remaining storage time in ice. The quality index method (QIM) provides weighted evaluation of the key parameters in deterioration of individual species, assigning demerit points according to the importance of each parameter. For the development and evaluation of QIM scheme, Frigate tuna were stored in ice and assessed raw and cooked. The QIM developed for raw Frigate tuna comprised of 11 parameters (appearance of skin and stiffness: cornea, form and colour of eyes; colour, smell and mucus of gills; condition of viscera; colour of blood and fillets) covering attributes, which gave a total of 25 demerit points. Sensory analysis of cooked Frigate tuna using Torry scheme were carried out in parallel to determine the shelf life. In order to obtain more information about the quality of Frigate tuna, Total viable counts (TVC), hydrogen sulphide $\left(\mathrm{H}_{2} \mathrm{~S}\right.$ ) producing bacteria, trimethylamine (TMA), total volatile basic nitrogen (TVN) content and $\mathrm{pH}$ value were determined.

The sensory evaluation was carried out by a panel of 6-7 judges and the rejection level was found to be 22 days. The QMM scheme developed for Frigate tuna showed a linear relationship between QMM scores and storage time in ice, $\left(\mathrm{T}^{2}=0.9378\right)$ with slope of 0.755 . The TVC varied from $10^{2} \mathrm{cfu} / \mathrm{g}$ to $10^{6} \mathrm{cfu} / \mathrm{g}$ within 7 to 22 days and $\mathrm{H}_{2} \mathrm{~S}$ producing bacteria at $10^{2} \mathrm{cfu} / \mathrm{g}$ within 22 days of storage in ice. The TMA and TVN amounts increased with time and the amounts ranged from $1.2 \mathrm{mg} / 100 \mathrm{~g}$ to $2.5 \mathrm{mg} / 100 \mathrm{~g}$ and 17.2 $\mathrm{mg} / 100 \mathrm{~g}$ to $34.9 \mathrm{mg} / 100 \mathrm{~g}$ respectively. The variation of $\mathrm{pH}$ ranged from 5.4 to 5.9 within the storage. 


\section{K. W.S. Ariyawansa et al.}

The QIM calibration curve obtained for Frigate tuna indicates its applicability to determine the storage life of fish in ice. Further, it will facilitate the requirements of buyers and sellers while fulfilling the demands of inspection authorities and the consumers.

\section{Introduction}

Improving the quality and the availability of fish for human consumption is an important area for management action. Handling and preservation of catch on board need to be improved, by using ice, chilled water, refrigeration/ freezing systems, etc. The fish that is landed must be kept clean and stored in ice, in refrigerated rooms or transported in ice, in refrigerated trucks depending on the duration of storage or transportation.

The freshness of fish deteriorates with time. Most of the changes resulting from loss of freshness can be evaluated by sight, touch, smell and taste which determine consumer acceptance. It is therefore extremely useful to have methods for describing the sensory properties of fish as a means of ascertaining their initial sensory characteristics and any changes undergone by the product in the course of storage.

The quality index method (QIM) is a very effective tool and a rapid and simple descriptive sensory method to determine freshness and quality (Bremner 1985; Bremner et al. 1985). QLM essentially evaluates those sensory parameters and attributes that change most significantly in each species during storage period (Huss 1995). By using QM, the fish inspector can give estimation of the past and remaining storage time. In addition, the knowledge of shelf life of fish species would allow fishermen, processors and retailers better control of their markets.

Regulations in European Union require freshness grading of most fish to be marketed within the union. Further, the fish inspection department has to perform quality inspection of fish prior to export in order to issue health certificate in accordance with EU regulations (EU Directive 1991). Fisheries and Aquatic Resources Act of 1996 also describes the freshness category of selected fish species (Fish Products (Export) Regulation 1998).

The aim of this study was to develop a quality index specific for raw fish of Frigate tuna (Auxis thazard) and predict the shelf life during ice storage and to compare the sensory analysis with microbial counts (total viable counts and $\mathrm{H}_{2} \mathrm{~S}$ producing bacteria) and chemical measurements.

\section{Materials and Methods}

A total of 70 fresh Frigate tuna (Awxis thazard) caught in Matara, the south cost of Sri Lanka were used in this experiment The fish which were 
kept in ice $18 \mathrm{hrs}$ after capture were brought to NARA laboratory. The first batch of Frigate tuna (30) was used for training of assessors, development of guality index and for photography. A batch of 40 fish was stored at $0^{\circ} \mathrm{C}$ to $2^{\circ} \mathrm{C}$ in iced boxes until analysis, which was used for test measurements and sensory evaluation.

The sensory evaluation of raw and cooked Frigate tuna were carried out in parallel on each sampling day (no. 1 , no. 7 , no. 12, no. 16, no. 19 and no. 22 days after capture) along with measurements of microbiological, chemical and $\mathrm{pH}$ Each sampling day, 5 Frigate tuna were used. Three fish were analyzed whole by QIM (Table 1). Pieces from one fish were steam cooked and evaluated with the Torry scheme (Table 2) for odour and flavour. Sensory assessments of cooked fish were carried out in parallel. Rest of the fish were used for microbiological analysis for TVC and $\mathrm{H}_{2} \mathrm{~S}$ producing bacteria (Gram et al. 1989), chemical analysis for TVN and TMA (Horwits 1980 ) and $\mathrm{pH}$ measurements. A panel of 5-7 trained judges evaluated the fish individually for each quality parameter in the scheme. Selected pictures were used to develop the QIM scheme for raw fish.

\section{Results}

The results from sensory evaluation, chemical measurements, microbial counts and $\mathrm{pH}$ are presented in relation to storage time of Frigate tuna in ice The sum of scores evaluated ranging from 0 for the best quality fish to 25 for the poorest quality fish. According to the QM scheme (Table 1) quality is presented as Quality Index (QI). The QI was linearly related to storage period $\left(\mathrm{R}^{2}=0.937\right)$ (Fig. 1).

The scores for all quality attributes of the QIM increased with storage time in ice (Figure 2). On the first day appearance of fish was scored 0-1, as the skin of fish was bright. On the $22^{\text {nd }}$ day fish were scoring 2 as the appearance of skin was dull. The skin did not become very soft after 22days of storage in ice. The scores of the quality attributes of gills increased with storage time. The colour approached maximum after 22 days in ice. The smell of gills did not reach the maximum of score of 3 , the average score of which was however above 1 after 16 days. The scores for gill odour appeared to have the same trend as gill mucus, but the average score reached around 2 at the end of storage time. The scores for viscera increased with storage time in ice, constantly. 


\section{K.W.S. Ariyawansa et al.}

Table 1. Quality Index method (QIM) scheme for Frigate tuna (Auxis thazard).

\begin{tabular}{|c|c|c|c|}
\hline $\begin{array}{l}\text { Quality } \\
\text { parameter }\end{array}$ & & Description & Seore \\
\hline \multirow[t]{7}{*}{ Appearance: } & \multirow[t]{3}{*}{ Skin } & Bright, iridescent pigmentation & 0 \\
\hline & & Rather dull, becoming discolored & 1 \\
\hline & & Dull & 2 \\
\hline & \multirow[t]{4}{*}{ Stiffness } & In rigor & 0 \\
\hline & & Firm, elastic & 1 \\
\hline & & 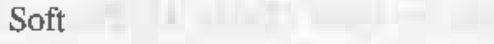 & 2 \\
\hline & & Very soft & 3 \\
\hline \multirow[t]{9}{*}{ Eyes: } & \multirow[t]{3}{*}{ Comea } & Clear & 0 \\
\hline & & Opalescent & 1 \\
\hline & & Milky & 2 \\
\hline & \multirow[t]{3}{*}{ Form } & Convex & 0 \\
\hline & & Flat, slightly sunken & 1 \\
\hline & & Sunken, concave & 2 \\
\hline & \multirow{3}{*}{$\begin{array}{l}\text { Colour of } \\
\text { Pupil }\end{array}$} & Black & 0 \\
\hline & & Opaque & 1 \\
\hline & & 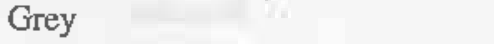 & 2 \\
\hline \multirow{8}{*}{ Gills: } & \multirow[t]{5}{*}{ Colour } & Bright & 0 \\
\hline & & I ass colored, becoming & 1 \\
\hline & & discoloured & \\
\hline & & Discolored, brown spots & 2 \\
\hline & & Brown, discolored & 3 \\
\hline & \multirow{2}{*}{ Smell } & Fresh, seaweedy, metallic & 0 \\
\hline & & Neutral, grassy, musty & 1 \\
\hline & \multirow{2}{*}{ 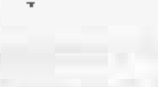 } & Yeast, bread, beer, sour milk & 2 \\
\hline . & & Acetic acid, sulphuric & 3 \\
\hline \multirow{3}{*}{ 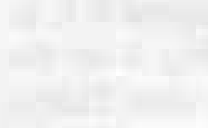 } & \multirow[t]{3}{*}{ Mucus } & Clear & 0 \\
\hline & & 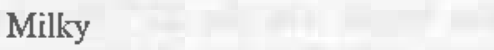 & 1 \\
\hline & & Milky, dark, opaque & 2 \\
\hline \multicolumn{2}{|l|}{ Viscera } & Whole & 0 \\
\hline \multirow{2}{*}{$x^{2}+x^{2}+x^{2}$} & & Beginning to get dissolved & 1 \\
\hline & & Viscera dissolved & 2 \\
\hline \multirow[t]{3}{*}{ Blood: } & \multirow[t]{3}{*}{ Color } & Red & 0 \\
\hline & & Dark red & 1 \\
\hline & & Brown & 2 \\
\hline \multirow[t]{3}{*}{ Fillets: } & \multirow[t]{3}{*}{ Color } & Translucent, bluish & 0 \\
\hline & & Waxy, milky & 1 \\
\hline & & Opaque, yellow, brown spots & 2 \\
\hline Quality Index & & & $:(0-25)$ \\
\hline
\end{tabular}


Quality index for Frigate tuna

Table 2. The score sheet for Tory scheme of freshness for cooked Frigate tuna (Awais thazard).

\begin{tabular}{|c|c|c|}
\hline Score & Odour & Flavour \\
\hline 10 & $\begin{array}{l}\text { Initially weak odour of boiled cod } \\
\text { liver, fresh oil, starchy }\end{array}$ & $\begin{array}{l}\text { Boiled cod liver } \\
\text { Watery, metallic }\end{array}$ \\
\hline 9 & $\begin{array}{l}\text { Shellfish, seaweed, } \\
\text { Boiled meat } \\
\text { Oil, cod liver }\end{array}$ & $\begin{array}{l}\text { Oily, boiled cod liver } \\
\text { Sweet, meaty, } \\
\text { Characteristic }\end{array}$ \\
\hline 8 & $\begin{array}{l}\text { Loss of odnur, } \\
\text { Neutral odour }\end{array}$ & $\begin{array}{l}\text { Sweet and characteristic } \\
\text { flavours but reduced in } \\
\text { intensity }\end{array}$ \\
\hline 7 & $\begin{array}{l}\text { Wood shavings, woodsap, } \\
\text { vanillin }\end{array}$ & Neutral \\
\hline 6 & $\begin{array}{l}\text { Condensed milk, } \\
\text { Boiled potato }\end{array}$ & Insipid \\
\hline 5 & $\begin{array}{l}\text { Milk jug odours, } \\
\text { boiled clothes-like }\end{array}$ & $\begin{array}{l}\text { Slight soumess, trace of } \\
\text { "off"-flavours, rancid }\end{array}$ \\
\hline 4 & $\begin{array}{l}\text { Lactic acid, sour milk, } \\
\text { TMA }\end{array}$ & $\begin{array}{l}\text { Slight bitterness, sour, } \\
\text { "off"-flavours, TMA, } \\
\text { rancid }\end{array}$ \\
\hline 3 & $\begin{array}{l}\text { Lower fatty acids (e.g. acetic or } \\
\text { butric acids) composed grass, } \\
\text { soapy, turnipy, tallowy }\end{array}$ & $\begin{array}{l}\text { Strong bitter, rubber, } \\
\text { slight sulphide, rancid }\end{array}$ \\
\hline
\end{tabular}

\section{Torry scheme}

Using Torry scheme (Table 2) cooked Frigate tuna was evaluated in parailel to the quality index method. High score (10) gives for the best quality and the low (3) score for the poorest quality. Scores for Frigate tuna stored 22 days in ice were found to be significantly different from those stored in ice for 1 to 7 days. The positive odour attributes, seaweed odour decreased with storage in ice and were hardly detectable after 12 days. The sour flavour decreased to unacceptable level of Frigate tuna for human consumption after 22 days in ice. Figure 3 shows the result of assessment of cooked fish using Torry scale during storage days in ice. 
K.W.S. Ariyawansa et al.

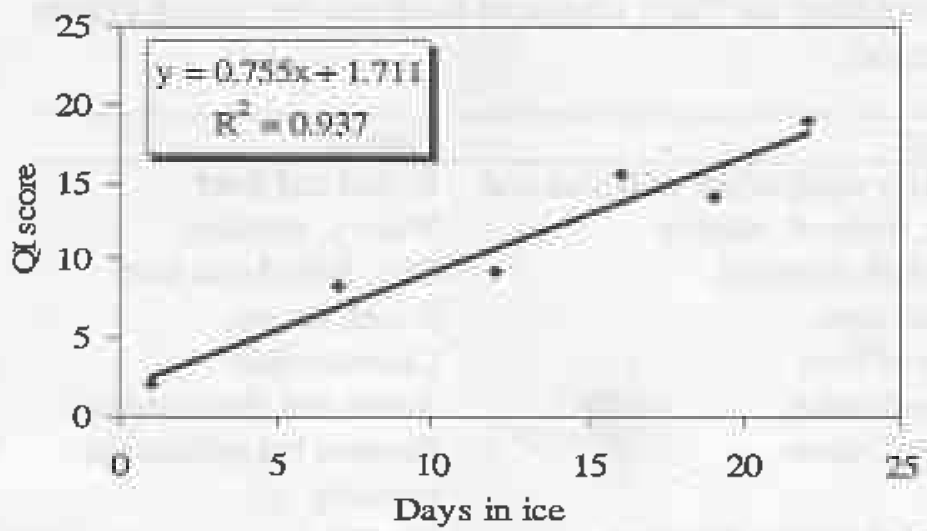

Figure 1. Relationship between Quality Index of Frigate tuna and storage period in ice.

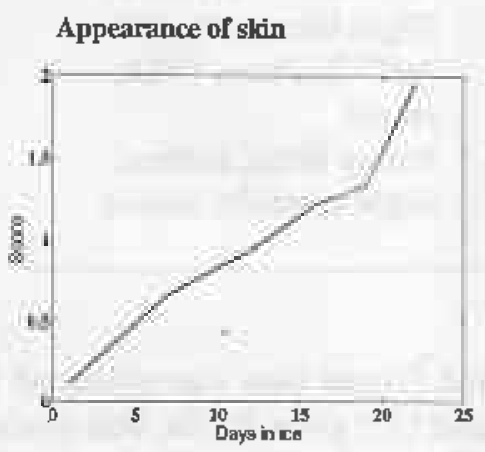

Eyes: Cornea

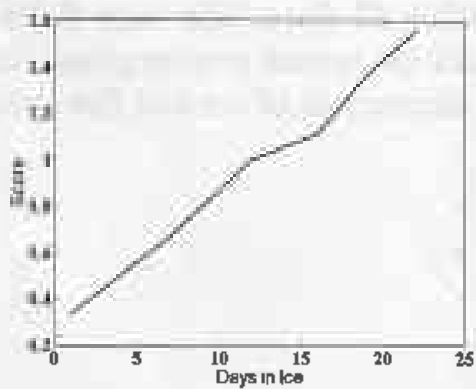

'Stifiness

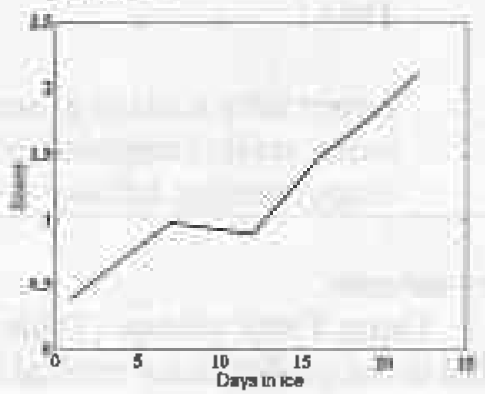

Eyes: Form

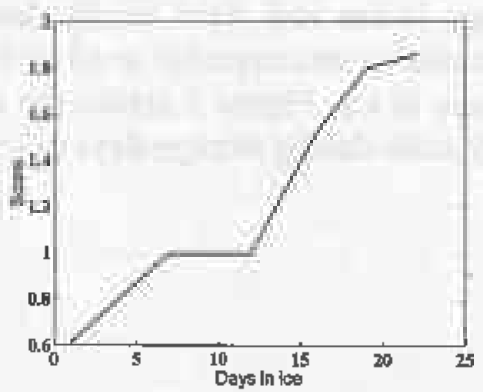

Figure 2. Average scores of each quality attribute assessed with QIM scheme for Frigate tuna stored in ice against days in ice. 
Quality index for Frigate tuna

Eyes: Colour of pupil

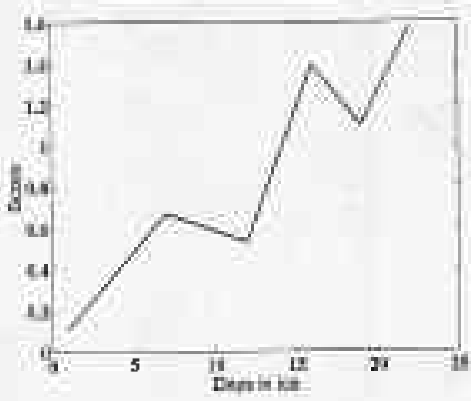

Gillsa Smeli

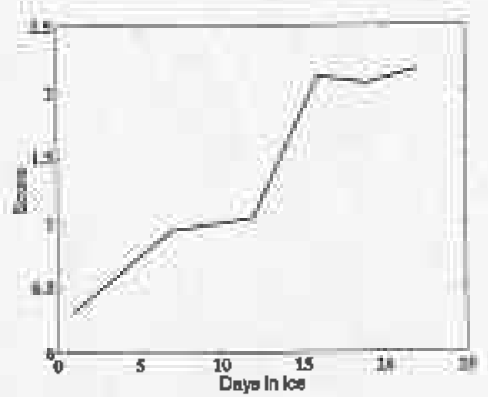

Blood: Colour

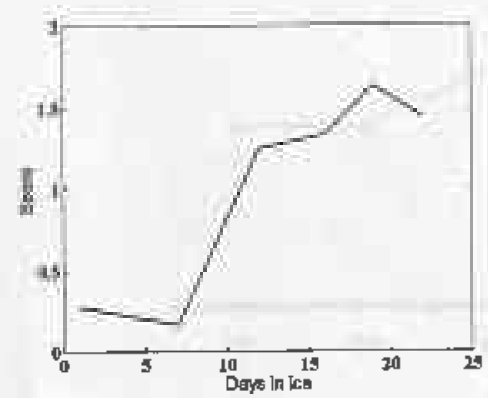

GIIls: Colour

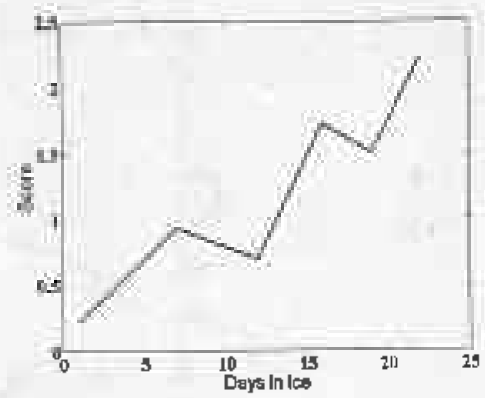

Gills: Mucus

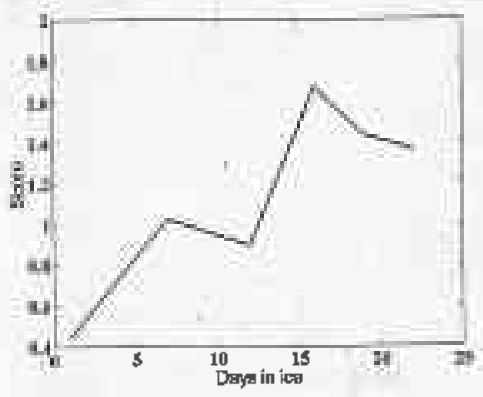

Fillets : Colour

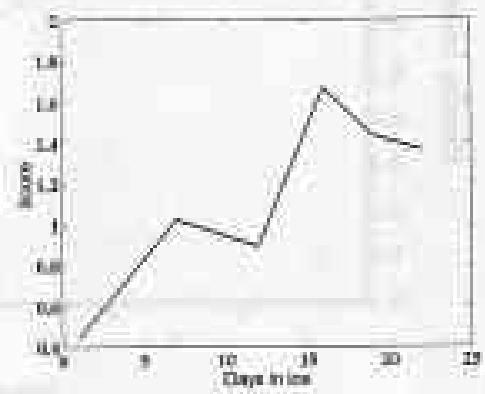

Figure 2. Average scores of each quality attribute assessed with QIM scheme for Frigate tuna stored in ice against days in ice (Continued). 
102

K.W.S. Ariyawansa et al.

Viscera

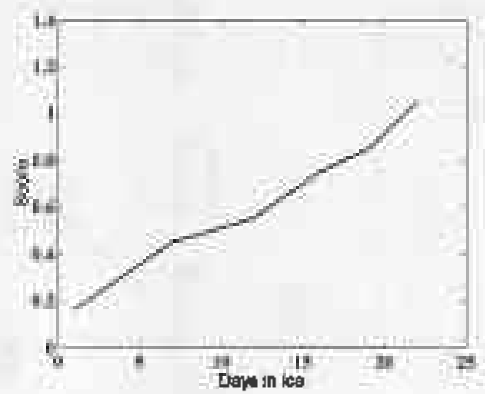

Figure 2. Average scores of each quality attribute assessed with QחM scheme for Frigate tuna stored in ice against days in ice (Continued).

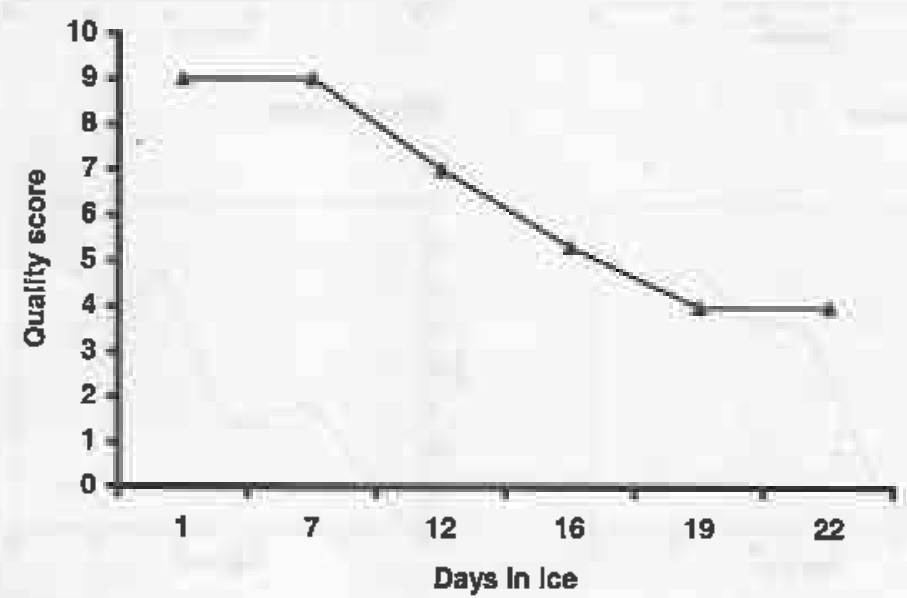

Figure 3. Quality scores of cooked fish based on odour and flavour during storage in ice 
Quality index for Frigate tuma

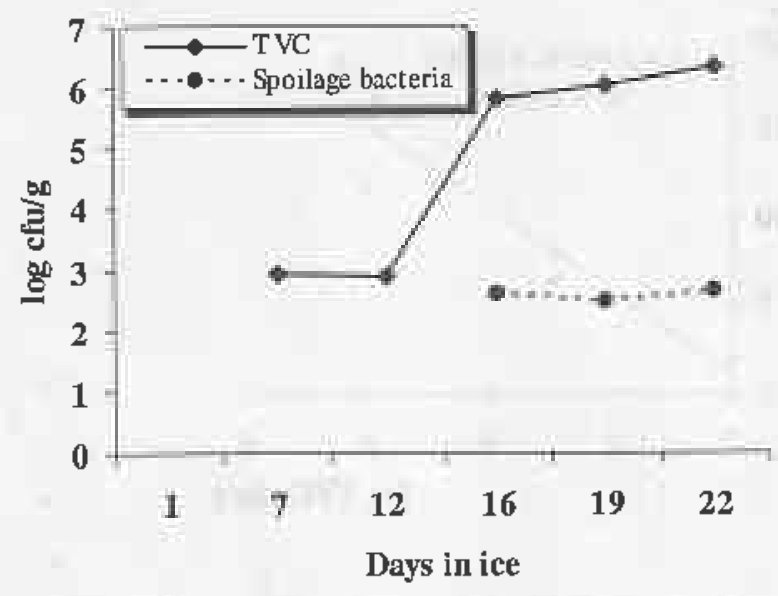

Figure 4. Hydrogen Sulphide $\left(\mathrm{H}_{2} \mathrm{~S}\right)$ producing bacteria (spoilage bacteria) and total viable counts (TVC) during storage in ice

A similar trend was evident in flavour as for odour. Positive attributes such as seaweed, sweet, metallic, oily flavour decreased with storage days in ice, while the negative attributes rancid, sour flavours increased with storage days. Especially the sour flavour was dominant after 22 days of storage, indicating that the Frigate tuna was of marginal acceptability. Some panelists were unable to detect some of the attributes.

\section{Microbial counts}

Total viable counts (TVC) increased with storage time starting from 7 days of storage (Fig. 4). When the fish reached the limits of acceptability (sensory score of 4 in Torry scheme), TVC reached level of $10^{6} \mathrm{cfu} / \mathrm{g}$.

Counts of $\mathrm{H}_{2} \mathrm{~S}$ producing bacteria could be detected in fish after 16 days of storage. Figure 4 shows that they were absent at the beginning and at the end of shelf life the counts were reached above $10^{2} \mathrm{cfu} / \mathrm{g}$.

As shown in figure 5, QI scores and $\log \mathrm{TVC}\left(\mathrm{R}^{2}=0.868\right)$ are highly correlated. 
104

K.W.S. Ariyawansa et al.

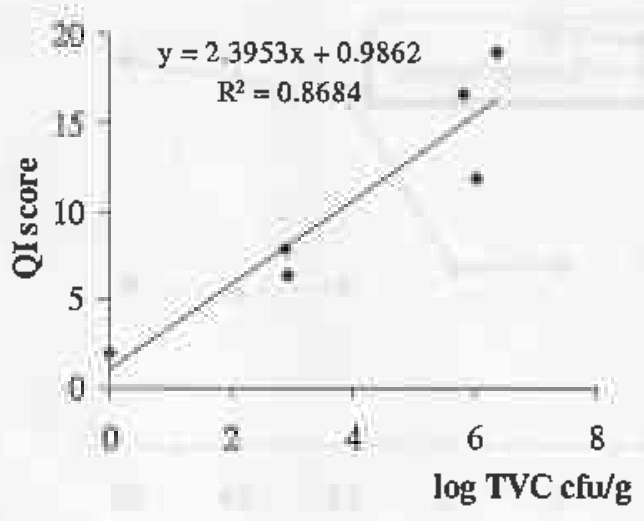

Figure 5. Conrelation between bacterial counts and quality index score.

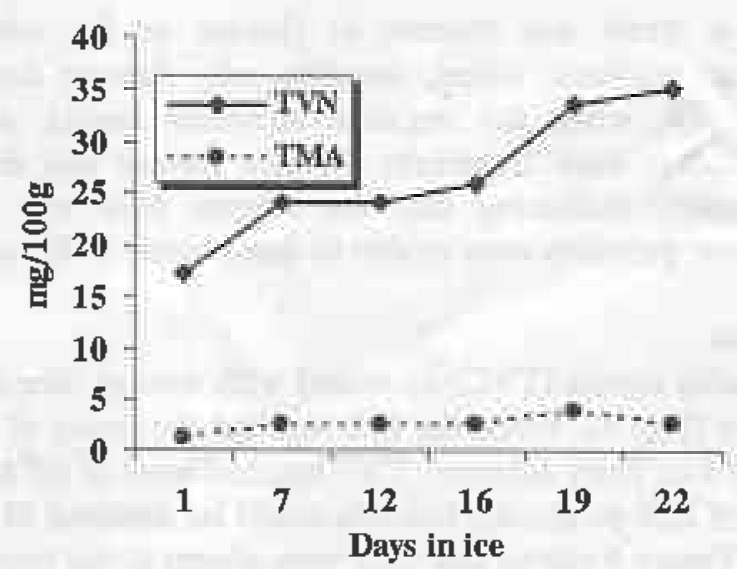

Figure 6. Total volatile nitrogen (TVN) and trimethylamine (TMA) in raw Frigate tuna during the storage period.

\section{Chemical analysis}

During storage in ice the concentrations of the Total Volatile Nitrogen (TVN) in tuna increased with time while Tri Methyl Amine (TMA) content remained more or less constant (Fig. 6). At the rejection time, TVN has reached the concentration of around $35 \mathrm{mg} / 100 \mathrm{~g}$ and TMA amount was $2.5 \mathrm{mg} / 100 \mathrm{~g}$. The TVN level is highly correlated to QI score (Fig. 7). 
Quality index for Frigate tuna

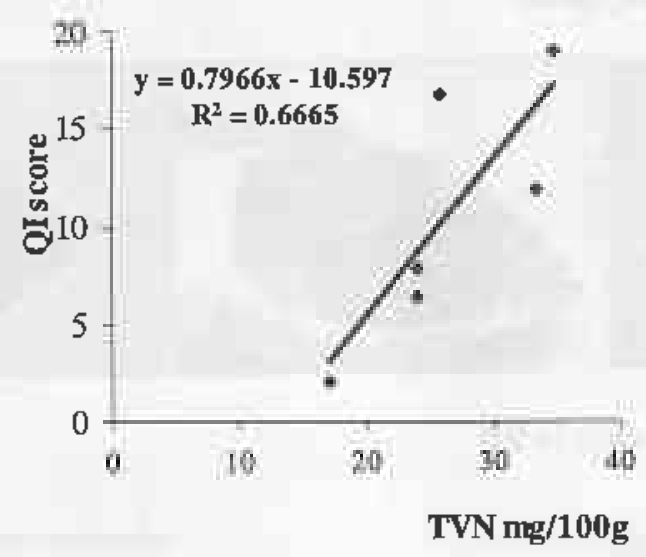

Figure 7. Correlation between TVN quality index score.

\section{pH measurements}

The $\mathrm{pH}$ value fluctuated slightly until 16 days, increased drastically until day 19 and decreased until 22 days (Fig. 8).

Photographs were used as guides for assessors to assess Frigate tuna by the QIM scheme on the basis of colour/appearance of whole fish, mucus and colour of gills and comea, form and colour of pupil. The photographs of Frigate tuna after 1, and 22 days in ice are shown in Figure 9.

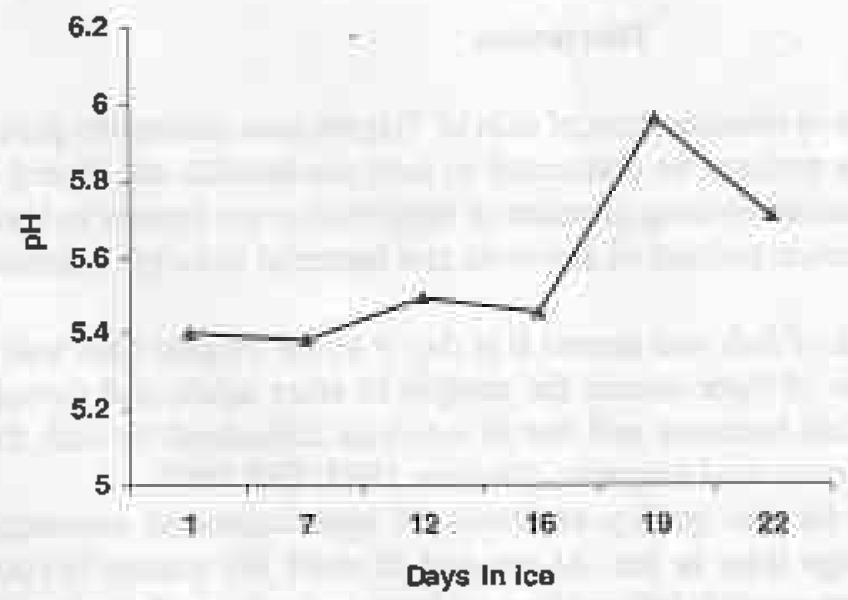

Figure 8. Changes in $\mathrm{pH}$ during storage of ungutted Frigate tuna in ice. 
Frigate tura stored 1 day in ice

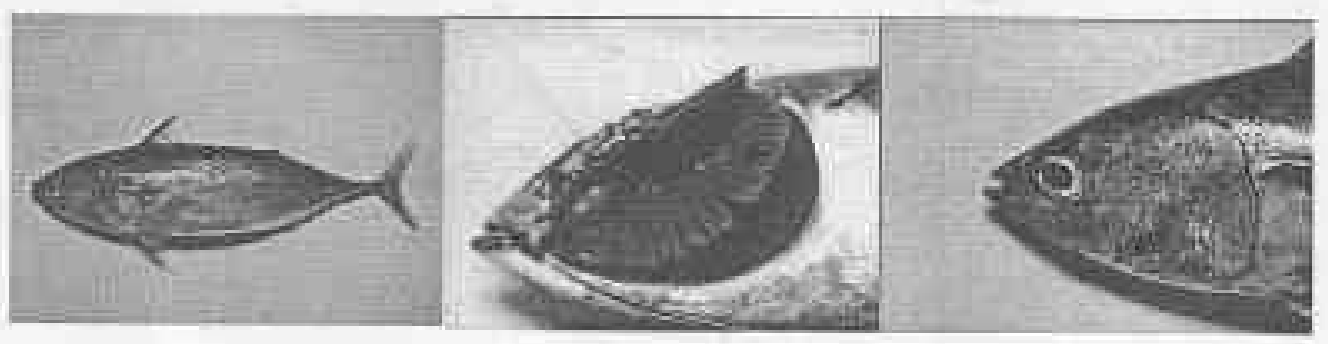

Frigate tuna stored 22 days in ice

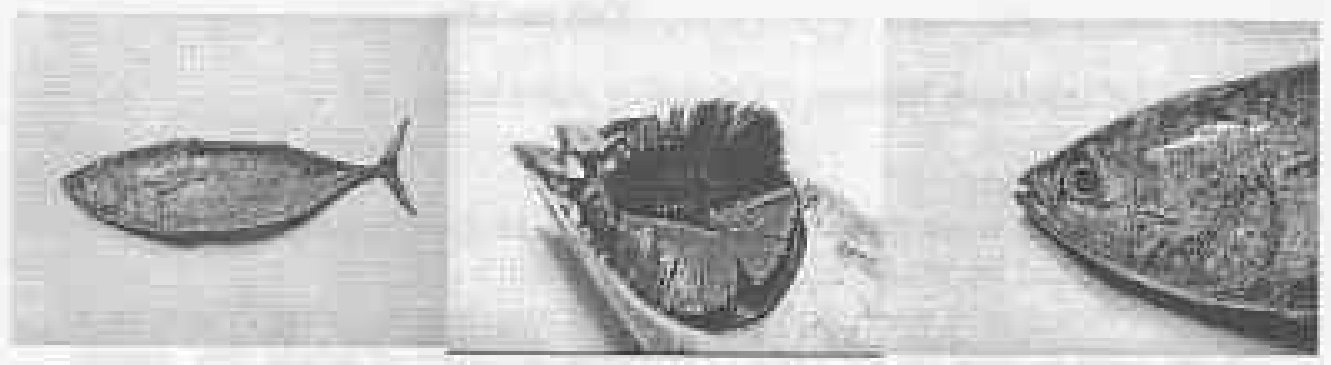

Figure 9: Photographs of Frigate tuna at three different stages, at the beginning of storage in ice ( 1 day in ice) and at rejection limit (22 days in ice).

\section{Discussion}

The increase in discoloration of skin of Frigate tuna during the period of storage in ice can perhaps be connected to how carotenoids are bound in the flesh. The carotinoid-binding proteins or lipoproteins are known to break down in the deterioration process of autolysis and bacterial activity (Torrissen et al. 1989).

The stiffness of fish was scored 0 at day 1 as the Frigate tuna was at rigor. The resolution of rigor causes the muscle to relax again and through storage in ice, the flesh becomes soft due to autolysis influenced by both fish muscle enzyme and microbial enzymes, (Nielsen 1995; Gill 1995).

The scores for the quality attributes of eyes increased constantly throughout the storage time in ice. At the end of shelf life comea become concave. Nevertheless enough information on form and colour of pupil could not be obtained. At the beginning of the storage time when the Frigate tuna was very fresh, the odour of gills was described as fresh sea weedy or neutral, This is probably because newly caught fish contains low levels of 
volatile compounds (Olafsdottir and Fleurence 1997). The score for colour of blood was close to 0 until 7 days in ice. The blood in the abdomen was blood red at first, but later on it became brownish. When the fish meat exists in the form of oxymyoglobin, this compound is oxidized to meta myoglobin, which is brown in colour. The increase in these negative odour attributes is caused by activity of spoilage bacteria producing substances of bad smell and oxidation of fat (Gram 1995; Jorgensen 1995). Milo and Grosh (1996) analyzed various odourants in salmon of different freshness levels. They found propionadehyde and (Z)-1,5-octadien-3-one as the most potent high volatile odorants in cooked fresh salmon samples. The odour of these compounds is described as sweet and metallic (respectively). Various odourants detected from cooked salmon (Milo and Grosh 1996) may also be responsible for the flavour and odour of cooked Frigate tuna. The odour and flavour were attributed to acetaldehyde (sweet), hexanal and $(Z, Z)-3,6-$ nonaldienal. The rancid odour increased in the last days of storage. The rancid flavour is known to be caused by formation of volatile oxidation products such as aldehydes and ketones (Milo and Grosh,1996). At the beginning, microbial counts in flesh of Frigate tuna were very low. It implies that flesh of healthy, live or newly caught fish is sterile as the immune system of the fish prevents the bacteria from growing in the flesh. When fish dies, the immune system collapses and during storage, bacteria invade the flesh (Gram 1995). Similar results were noted by Lande and Rora (1999). Magnusson (1987) found TVC and $\mathrm{H}_{2} \mathrm{~S}$ producing bacteria in farmed salmon, whose the total viable count reached $10^{5} \mathrm{cfu} / \mathrm{g}$ in flesh after the storage time of 22 days. In ice stored Nile perch the total counts were at $10^{9} \mathrm{cfu} / \mathrm{g}$ on the day before the fish was rejected (Gram et al. 1989).

For the TVN concentration in muscle tissue of certain fish species a legal limit has been fixed by the EC-commission at $25 \mathrm{mg} / 100 \mathrm{~g}$. TVN is produced mainly by $\mathrm{H}_{2} \mathrm{~S}$ producing bacteria. In the present study, that is detected after 16 days in ice. TMA is a pungent volatile amine often associated with the typical "fishy" odour of spoiling seafood. TMA and many other amines become volatile at elevated $\mathrm{pH}$.

The low value of $\mathrm{pH}$ in first day of storage could be explained by "post mortem" glycolysis that results in the accumulation of lactic acid, which in turn lower the $\mathrm{pH}$ of muscle. Huss (1995) has reported $\mathrm{pH}$ drops from 6.8 to $6.1-6.5$ in cod and 6.8 to 5.4-5.6 in tuna and halibut. The increase in $\mathrm{pH}$ with storage time is probably caused by formation of basic compounds (Huss 1988).

The changes occurring in the outer appearance of Frigate tuna with storage days in ice are presented in Figure 9. The appearance of the skin changes from being pearl-shiny to dull, the eyes change from being black and convex to grey and sunken. The gills change from red with clear mucus to 
brownish with clotted, brown mucus. All those changes are listed in QIM scheme for Frigate tuna, with photographs when possible, making it easier to assess the freshness stage of Frigate tuna.

\section{Acknowledgement}

The authors wish to acknowledge with thanks the cooperation extended by Mrs. K.S. Hettiarachchi, Mrs. J.M. Chandrika and Mr. S.P. Jayasooriya during the course of the study. This project was funded by NARA.

\section{References}

Bremner H.A. 1985.

A convenient easy to use system for estimating the quality of chilled seafood. Fish Processing Bulletin 7: 59-703.

Bremner H.A., J. Olley \& A.M.A.Vail 1985.

Estimating time-temperature effects by a rapid systematlc sensory method. In: Proceedings of an international symposium on seafood quality determination, Alaska, U.S.A. (D.E. Kramer and L. Liston eds), Elsevier, Amsterdam. 413-435 pp.

EU directive 1991.

Council Directive 91/493 /EEC.

Gill T. 1995.

Autolytic changes. In: Quality and quality changes in fresh fish. (H.H. Huss ed.). FAO technical paper, No. 348. FAO, Rome. 45-50 pp.

Gram L. 1995.

Bacteriological changes. In: Quality and quality changes in fresh fish. (H.H. Huss ed.). FAO technical paper, No. 348. FAO, Rome. 51-63 pp.

Gram L., G. Trolle \& H.H. Huss 1989.

Detection of specific spoilage bacteria from fish stored at low $\left(0^{\circ} \mathrm{C}\right)$ and high $\left(20^{\circ} \mathrm{C}\right)$ temperatures. Journal of Food Microbiology 4: 6572 .

Gram L., J. Oundo \& J. Bon 1989.

Storage life of Nile perch (Lates niloticus) dependent on storage temperature and initial bacterial load. Tropical Science 29: 221-236.

Horwits W. 1980.

Official Methods of Analysis Association of Official Analytical Chemists, Washington. DC-20044, USA. 
Huss H.H. 1988.

Fresh fish quality and quality changes. FAO Fisheries Series 29. FAO, Rome. 27-61 pp.

Jorgensen B. 1995. Lipid oxidation and hydrolysis. In: Quality and quality changes in fresh fish (H.H. Huss ed.). FAO technical paper No. 348. FAO, Rome. 64-67 pp.

Lande A. \& M.B. Rora 1999.

Holdbarhet av iset laks. Norsk Fiskeoppdrett nr. 5a: 6-7.

Magnusson H. 1987.

Geynnslupol a eldislaxi. Rannsoknastofnum fiskidnadarins, Rekjavik.

Milo C. \& W.Grosch 1996.

Changes in the odorants of boiled Salmon and Cod as affected by the storage of the raw material. Journal of Agriculture and Food Chemistry. 44: 2366-2371.

Nielsen J. 1995.

Sensory methods. In: Quality and quality changes in fresh fish (H.H. Huss ed.). FAO technical paper No. 348. FAO, Rome. 130-139 pp.

Olafsdottir G. \& L. Fleurence 1997.

Evaluation of fish freshness using volatile compounds-classification of volatile compounds in fish. In: Methods to determine the freshness of fish (G. Olfsdottir et al. eds). Proceedings of the final meeting of the concerted action. Evaluation of fish freshness. Nantes 55-69 pp.

Torrissen O.J., R.W. Hardy \& Shearer 1989. Pigmentation of salmonoids carotenoid deposition and metabolism. CRC Crit. Rev. Aquatic Science 1: 209-225.

The Gazelte of the Democratic Socialist Republic of Sri Lanka. Extraordinary. Fish products (Export) Regulation 1998. No. 1230/14, 03.04.2002. 